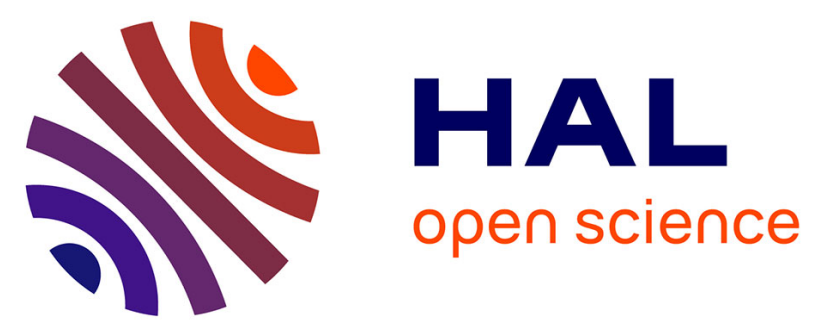

\title{
TGF- $\beta 1$ gene polymorphism in renal transplant patients with and without gingival overgrowth
}

Malgorzata Kozak, Mateusz Kurzawski, Anna Wajda, Joanna Lapczuk, Mariusz Lipski, Krzysztof Dziewanowski, Marek Drozdzik

\section{To cite this version:}

Malgorzata Kozak, Mateusz Kurzawski, Anna Wajda, Joanna Lapczuk, Mariusz Lipski, et al.. TGF- $\beta 1$ gene polymorphism in renal transplant patients with and without gingival overgrowth. Oral Diseases, 2011, 17 (4), pp.414. 10.1111/j.1601-0825.2010.01769.x . hal-00613925

\section{HAL Id: hal-00613925 \\ https://hal.science/hal-00613925}

Submitted on 8 Aug 2011

HAL is a multi-disciplinary open access archive for the deposit and dissemination of scientific research documents, whether they are published or not. The documents may come from teaching and research institutions in France or abroad, or from public or private research centers.
L'archive ouverte pluridisciplinaire HAL, est destinée au dépôt et à la diffusion de documents scientifiques de niveau recherche, publiés ou non, émanant des établissements d'enseignement et de recherche français ou étrangers, des laboratoires publics ou privés. 


\section{ORALIDISEASES}

TGF- $\beta 1$ gene polymorphism in renal transplant patients with and without gingival overgrowth

\begin{tabular}{|c|c|}
\hline Journal: & Oral Diseases \\
\hline Manuscript ID: & ODI-06-10-OM-1694.R2 \\
\hline Manuscript Type: & Original Manuscript \\
\hline $\begin{array}{r}\text { Date Submitted by the } \\
\text { Author: }\end{array}$ & 02-Sep-2010 \\
\hline Complete List of Authors: & $\begin{array}{l}\text { Kozak, Malgorzata } \\
\text { Kurzawski, Mateusz } \\
\text { Wajda, Anna } \\
\text { Lapczuk, Joanna } \\
\text { Lipski, Mariusz } \\
\text { Dziewanowski, Krzysztof } \\
\text { Drozdzik, Marek; Pomeranian Medical University, Pharmacology }\end{array}$ \\
\hline Keywords: & Genetics, Medicine \\
\hline
\end{tabular}

SCHOLARONE $^{\text {m }}$

Manuscripts 
TGF- $\beta 1$ gene polymorphism in renal transplant patients with and without gingival overgrowth

\author{
M Kozak ${ }^{1}$, M Kurzawski $^{1}$, A Wajda ${ }^{1}$, J Lapczuk $^{1}$, M Lipski $^{2}$, K Dziewanowski $^{3}$, M Drozdzik $^{1}$ \\ Departments of ${ }^{1}$ Pharmacology, ${ }^{2}$ Department of Preclinical Conservative Dentistry and Preclinical \\ Endodontics, Pomeranian Medical University, Szczecin, Poland; ${ }^{3}$ Department of Nephrology, \\ County Hospital, Szczecin, Poland
}

Short title: TGF- $\beta 1$ gene polymorphism in gingival overgrowth

Correspondence: Marek Drozdzik, MD, PhD, Department of Pharmacology, Pomeranian Medical University, Powstancow Wlkp. 72 Street, 70-111 Szczecin, Poland.

Tel: +4891 4661589; fax: +4891 4661600; E-mail: drozdzik@sci.pam.szczecin.pl 
BACKGROUND: The incidence of gingival overgrowth among renal transplant patients treated with cyclosporine A ranges from 13 to $84.6 \%$, and the overgrowth is not only esthetic but also medical problem. The study was aimed at determination of association between TGF- $\beta 1$ gene (TGFB 1) polymorphism and gingival overgrowth in kidney transplant patients medicated with cyclosporin A.

METHODS: 84 kidney transplant patients with gingival overgrowth and 140 control transplant patients without overgrowth were enrolled into the case control study. TGFB1 polymorphism was determined using the PCR-RFLP assay for $+869 \mathrm{~T}>\mathrm{C}$ in codon 10 and $+915 \mathrm{G}>\mathrm{C}$ in codon 25 as well as TaqMan real-time PCR assays for promoter $-800 \mathrm{G}>\mathrm{A}$ and $-509 \mathrm{C}>\mathrm{T}$ SNPs.

RESULTS: In kidney transplant patients suffering from gingival overgrowth mean score of gingival overgrowth was $1.38 \pm 0.60$, whereas in control subjects was 0.0 . The patients with gingival overgrowth were characterized by similar distribution of TGFB1 genotypes and allele in comparison to subjects without gingival overgrowth. Among 16 potentially possible haplotypes of TGFB1 gene, only four were observed in the studied sample of kidney transplant patients: G_C_T_G, G_T_C_G, G_C_C_C, and A_C_T_G, with similar frequency in patients with and without gingival overgrowth.

CONCLUSION: No association between the $T G F B 1$ gene polymorphism and gingival overgrowth was revealed in kidney transplant patients administered cyclosporine A.

Key words: TGF- $\beta 1$; gingival overgrowth; polymorphism 


\section{Introduction}

Gingival overgrowth frequently occurs in transplant patients receiving immunosuppressive drugs such as cyclosporine (INN ciclosporin), which has been widely used since 1970s. The incidence of gingival overgrowth among renal transplant patients treated with cyclosporine A ranges from 13 to 84.6\% (Somacarrera et al, 1994; Margiotta et al, 1996; Pernu et al, 2001; Afonso et al, 2003). Gingival overgrowth induced by cyclosporine A is probably the consequence of alterations in the turnover of epithelial and connective tissues, resulting in an increase in structural proteins sometimes associated with epithelial thickening. Numerous studies have investigated potential risk factors in the development of the condition, including the extent of renal disease, interval since transplantation, duration of renal replacement therapy, dose of cyclosporine A, gingival inflammation, plaque indices and recipient HLA-phenotype. Whilst some studies have suggested some associations between the incidence and severity of gingival overgrowth and sex, pre-transplant diagnosis, age at transplantation, duration of therapy and cyclosporine dosage, others have failed to find any significant drug-related risk factors for the development of the disease as previously reported (Seymour et al. 1996; Thomas et al. 2000; Thomas et al. 2001; Afonso et al. 2003). However, it remains unclear why a proportion of patients are susceptible to gingival overgrowth while others remain unaffected.

It was hypothesized, that gingival overgrowth induced by cyclosporine results in a disturbance in the homeostatic balance which is characterized by an increase in both the number of fibroblasts and an increase in the volume of the extracellular matrix. This loss of growth control results in an accumulation of redundant tissue of relatively normal composition (McGaw et al, 1988). There is considerable information supporting the role for transforming growth factor- $\beta 1$ (TGF- $\beta 1$ ) in mediation the dysregulated fibroblast proliferation and extracellular matrix synthesis. Evidence from experimental studies demonstrate that gingival fibroblasts in culture exhibit a proliferative response to TGF- $\beta 1$ (Anderson et al, 1998; James et al, 1998). It was also reported that TGF- $\beta 1$ suppresses extracellular matrix degradation via downregulation of metalloproteinases (MMP) production and inducing tissue inhibitor of MMP synthesis (Edwards et al, 1987; Overall et al, 1989). Also, administration of TGF- $\beta 1$ antisense oligonucleotide increase the expression of collagen degrading enzymes in human gingival fibroblasts (Cotrim et al, 2002). Experimental data also revealed that proliferation of rat gingival cells under cyclosporine A depended on TGF- $\beta 1$ mRNA induction by the drug (Yoshida et al, 2005). Clinical studies demonstrated that circulating and gingival crevicular fluid levels of TGF- $\beta 1$ were increased in cyclosporin-medicated transplant patients (Buduneli et al, 2001), and TGF- $\beta 1$ was found to be an independent risk factor for gingival overgrowth in immunosuppressed patients, also medicated with cyclosporine A (Ellis et al, 2004; 
Gurkan et al, 2008). Recently, an accumulation of extracellular matrix related to TGF- $\beta 1$ overexpression in cultured fibroblasts from patients medicated with cyclosporine $\mathrm{A}$ has been reported by Dreyfuss et al (2010).

It was reported that expression of TGF- $\beta 1$ gene (TGFB1) may depend on genetic constitution, i.e. within the TGFB1 some functional SNPs were defined. Clinical studies in kidney transplant patients medicated with cyclosporine A suggested an association between TGFB1 gene polymorphism located in coding regions (codon $10-+869 \mathrm{~T}>\mathrm{C}$ Pro10Leu and codon $25+915 \mathrm{G}>\mathrm{C}$ Arg25Pro) and gingival overgrowth (Linden et al, 2001; Radwan-Oczko et al, 2006). However, contradictory results in kidney transplant patients with respect of the same as aforementioned SNPs are also available (Radwan-Oczko et al, 2008).

Therefore, it was decided to investigate the role of four SNPs within TGFB1 gene, previously associated with alterations in gene expression level, in gingival overgrowth in kidney transplant patients medicated with cyclosporine A. Two of the SNPs were previously evaluated, and lead to aminoacid substitution: $+869 \mathrm{~T}>\mathrm{C}$ in codon 10 (rs1800470, Pro10Leu) and $+915 \mathrm{G}>\mathrm{C}$ in codon 25 (rs1800471, Arg25Pro). The other two SNPs are located in promoter region of TGFB1: $-800 \mathrm{G}>\mathrm{A}$ (rs1800468), and -509C $>\mathrm{T}$ (rs1800469), and thus can affect promoter function and gene expression (Grainger et al., 1999; Grainger et al., 2000).

\section{Materials and Methods}

The protocol of the study was approved by the ethics committee of the Pomeranian Medical University, Szczecin, Poland, i.e. the experiments were undertaken with the understanding and written consent of each subject and according to ethical principles, including the World Medical Association Declaration of Helsinki (version, 2002). Patients of Polish origin, Caucasians, hospitalized and than followed-up at the Department of Nephrology, County Hospital, Szczecin, Poland were recruited into the study from 2002 to 2010 year, after giving informed consent. A total of 84 unrelated kidney transplant patients suffering from gingival overgrowth (61 males, 23 females) aged from 16 to 70 years (mean $42.2 \pm 13.1$ years) were enrolled into the study. All patients were examined by two independent consultant periodontal specialists 6 months after kidney transplantation. Periodontists were blinded to SNP status. The patients were assessed using a clinical scoring method according to Pernu et al (1992). The patients were ascribed a general wholemouth score of between 0 and 3: $0=$ no overgrowth seen; $1=$ mild gingival overgrowth (thickening of the marginal gingiva and/or lobular granulation of the gingival pocket as well as overgrowth covering the gingival third of the crown or less); $2=$ moderate gingival overgrowth (overgrowth 
extending to the middle of the crown); $3=$ severe gingival overgrowth (overgrowth covering two thirds of the crown or affectation of the whole attached gingiva).

Control samples were from 140 kidney transplant patients (91 males, 49 females), aged from 17 to 66 years (mean $39.7 \pm 11.4$ years), who were free from gingival overgrowth signs at 6 months after transplantation, as evaluated by consultant periodontal specialists. Patients' characteristics are shown in table 1.

During the study period all subjects were administered cyclosporin A, azathioprine, prednisone and one of two calcium channel blockers, i.e. diltiazem or verapamil; eight patients without gingival overgrowth were given atenolol or prazosine. The medication regimens administered in both groups of the study, including cyclosporin A dose and concentrations, dosages of verapamil, diltiazem and prednisone evaluated at monthly intervals during 6 months were comparable, i.e. all calculated pvalues were $>0.05$ (Table 2). The serum concentrations of cyclosporin A were measured by fluorescence polarization immunoassay using TDx analyzer (Abbott) in all patients.

\section{Genotyping}

Four SNPs within $T G F B 1$ gene, previously associated with alterations in gene expression level were selected for the purpose of this study. Two of them are located in promoter region of TGFB1: $-800 \mathrm{G}>\mathrm{A}$ ( $\mathrm{rs} 1800468)$, and $-509 \mathrm{C}>\mathrm{T}$ ( $\mathrm{rs} 1800469)$, the others lead to aminoacid substitution: $+869 \mathrm{~T}>\mathrm{C}$ (rs1800470, Pro10Leu) and $+915 \mathrm{G}>\mathrm{C}$ (rs1800471, Arg25Pro). Genomic DNA was extracted from $200 \mu \mathrm{L}$ of whole blood samples using GeneMATRIX Quick Blood DNA Purification Kit (EURx, Poland). Each individual was genotyped for a presence of 4 SNPs in TGFB1 gene. The allelic discrimination TaqMan real-time PCR assays (Assay IDs: C_8708474_20, C_8708473_10, and C_22272997_10, Applied Biosystems, USA) were used for detection of $-800 \mathrm{G}>\mathrm{A},-509 \mathrm{C}>\mathrm{T}$ and $+869 \mathrm{~T}>\mathrm{C}$ SNPs, respectively. Fluorescence data was captured using an ABI PRISM 7500 FAST Real-Time PCR System (AppliedBiosystems), after 40 cycles of PCR. For analysis of $+915 \mathrm{G}>\mathrm{C}$ polymorphism, a PCR-RFLP method was applied. Briefly, polymerase chain reaction was performed in $15 \mu \mathrm{l}$ of total volume, with a pair of primers: 5'-cgc tge tgt gge tac tgg t-3', and 5'-ctc cgg ttc tgc act ctc c-3', previously described by Pulleyn et al. [2001]. Subsequently, a 254 bp PCR product was digested with the Cfr13I endonuclease (Fermentas, Lithuania), yielding two DNA fragments $(171+83 \mathrm{bp})$ in case of wild-type $\mathrm{G}$ allele. The $+915 \mathrm{G}>\mathrm{C}$ substitution creates additional restriction site recognized by Cfr 13I, yielding 3 fragments $(141+83+30 \mathrm{bp})$, which was visualized after electrophoresis in 3.5\% agarose gels stained with ethidium bromide (Pulleyn et al, 2001). 


\section{Statistical analysis}

The data were tested for Hardy-Weinberg equilibrium by calculating expected frequencies of genotypes and comparing them to the observed values using the $\chi 2$ test (Statistica 8.0, Statsoft Software, Warsaw, Poland). Associations between categorical variables were assessed by the Fisher exact test. The EH program (Jurg Ott, Rockefeller University, New York) was used to estimate haplotype frequencies. Linkage disequilibrium (LD) was measured as followed - the D' was calculated using 2LD software and squared correlation coefficient $\left(\mathrm{r}^{2}\right)$ was evaluated. Odds ratios $(O R)$ and $95 \%$ confidence interval $(95 \% C I)$ were calculated using the Newcombe-Wilson method without the continuity correction. A $p$ level of less than 0.05 was considered statistically significant.

\section{Results}

Out of 84 patients with gingival overgrowth, 57 subjects were classified as score 1 of gingival overgrowth, 22 patients were ascribed score 2 and 5 subjects score 3. Mean score of gingival overgrowth was $1.38 \pm 0.60$ according to Pernu's scoring system (Pernu et al, 1992). Control transplant patients were characterized by healthy gingiva, i.e. were scored 0 .

The genotype frequency distribution for all analyzed SNPs did not show a significant deviation from Hardy-Weinberg equilibrium in any of the study groups $(\mathrm{p}>0.1)$. The distribution of TGFB1 gene genotypes and alleles in kidney transplant patients is shown in Table 3. The patients with gingival overgrowth induced by immunosuppressive medication were characterized by similar distribution of $T G F B 1$ genotypes and allele to subjects without overgrowth, i.e. SNPs within the two coding regions: $+869 \mathrm{~T}>\mathrm{C}$ in codon 10 (rs1800470, Pro10Leu) and $+915 \mathrm{G}>\mathrm{C}$ in codon 25 (rs1800471, Arg25Pro) as well as two promoter region SNPs: -800G $>$ A (rs1800468), and $-509 \mathrm{C}>\mathrm{T}$ (rs 1800469). In the next step of the study we subjected for analysis haplotypes of TGFB1 gene (Table 4). The results of linkage analysis showed that all analysed SNPs are in strong linkage in a Polish population (Figure 1). The EH program (Jurg Ott, Rockefeller University, New York) was used to estimate haplotype frequencies based on results of typing for the following studied SNPs: $-800 \mathrm{G}>\mathrm{A},-509 \mathrm{~T}>\mathrm{C},+869 \mathrm{~T}>\mathrm{C},+915 \mathrm{G}>\mathrm{C}$. Among 16 potentially possible haplotypes derived from 4 SNPs, only four were observed in the studied sample of kidney transplant patients, with respective frequencies: G_C_T_G (0.545), G_T_C_G (0.324), G_C_C_C (0.071), and A_C_T_G (0.060). Similarly to distribution of the genotypes and allele, frequency of TGFB1 haplotypes were comparable in kidney transplant patients with and without gingival overgrowth.

\section{Discussion}

TGF- $\beta 1$ patophysiological data as well as reports on functional polymorphism of its gene - TGFB1 
suggest potential role of the cytokine and polymorphism in the pathology of drug-induced including cyclosporin A, gingival overgrowth (Edwards et al, 1987; Anderson et al, 1998; James et al, 1998; Overall et al, 1989; Grainger et al, 1999; Grainger et al, 2000 Buduneli et al, 2001; Cotrim et al, 2002; Ellis et al, 2004; Yoshida et al, 2005; Gurkan A et al, 2008). However, available data on the effects of TGFB1 gene polymorphism on gingival overgrowth in kidney transplant patients medicated with cyclosporin A are controversial. Linden et al (2001) and Radwan-Oczko et al (2006) revealed that polymorphisms in TGFBl gene located in coding regions of the gene, i.e. codon $10-+869 \mathrm{~T}>\mathrm{C}$ Pro10Leu and codon $25+915 \mathrm{G}>\mathrm{C}$ Arg25Pro are genetic factors associated with risk of gingival overgrowth. Subsequent report from the latter group (Radwan-Oczko et al, 2008) showed that the aforementioned polymorphisms are not associated with gingival overgrowth observer in kidney transplant patients medicated with cyclosporin A.

Therefore, it was decided to evaluate TGFB1 gene polymorphism in kidney transplant patients medicated with cyclosporine A. The former studies included polymorphisms in the coding regions of the gene resulting in aminoacid substitutions, namely in codon $10-+869 \mathrm{~T}>\mathrm{C}$ Pro10Leu and codon 25 +915G >C Arg25Pro (Linden et al, 2001; Radwan-Oczko et al, 2006; Radwan-Oczko et al, 2008). However, it is well known that polymorphisms located in promoter region of the gene can also be functional, affecting expression level of genes, hence in the present study polymorphisms in the promoter of TGFB1 gene were evaluated at positions $-800 \mathrm{G}>\mathrm{A}$ and $-509 \mathrm{C}>\mathrm{T}$ (Grainger et al, 1999; Grainger et al, 2000). The promoter polymorphisms, although functional, have not been studied in posttransplant patients with gingival overgrowth yet. Furthermore, we evaluated haplotypes of $T G F B 1$ gene as potential risk factors associated with gingival overgrowth in patients administered cyclosporine A.

Previous reports, similarly to our report included patients from Caucasian populations, but number of cases analysed was smaller than in the present study, study by Linden et al (2001) involved 164 kidney transplant patients medicated with cyclosporin A (of them 46 with gingival overgrowth), by Radwan-Oczko et al from 2006 comprised 92 cases (of them 50 with gingival overgrowth) and Radwan-Oczko et al from 2008 included 98 subjects (of them 54 with gingival overgrowth). The present study recruited 224 patients, including 84 with gingival overgrowth. Having in mind power of the study the present report seems to be most reliable in comparison to the further studies. The results of the present study are in line with the report of Radwan-Oczko et al (2008) demonstrating no association of the coding region polymorphisms of TGFB1 gene and gingival overgrowth, contrary to studies of Linden et al, 2001 and Radwan-Oczko et al 2006. The present study was extended to functional polymorphisms located in promoter region of the TGFB1 gene, and similarly to results from coding regions any associations of genetic factors with gingival overgrowth in 
kidney transplant patients were revealed. Finally, haplotype frequencies based on results of typing for the studied SNPs: $-800 \mathrm{G}>\mathrm{A},-509 \mathrm{~T}>\mathrm{C},+869 \mathrm{~T}>\mathrm{C}$, $+915 \mathrm{G}>\mathrm{C}$ were analysed. Similarly to genotypes, the analysed haplotypes did not discriminate the studied groups, i.e. kidney transplant patients medicated with cyclosporin A with and without gingival overgrowth.

Interaction between simultaneously administered drugs affecting enlargement have been also reported. Cyclosporin A-treated patients are often comedicated with azathioprine and prednisolone, which can modify the severity of gingival overgrowth (Wilson et al, 1998). In contrast patients on cyclosporin A who are also receiving calcium channel blockers present with a greater risk of the gingival lesions than patients treated with cyclosporine alone (Thomasson et al, 1997). However, in the present study, both groups, i.e. patients with and without gingival overgrowth were medicated similarly during observation period. So, the effect of treatment modality of gingival pathology could be neglected in the data analysis.

Another factor which could potentially influence the study conclusions is a number of evaluated cases. As in the present study analysed groups comprised of 84 and 140 cases the conclusions drawn should be considered as preliminary data, and the results of the study should be confirmed by observations from other populations involving larger groups of patients.

Based on the results from the present study it can be concluded that there is no significant association between the TGFB1 gene polymorphism and gingival overgrowth in kidney transplant patients administered cyclosporine A as a principal immunosuppressive agent.

\section{Acknowledgements}

The study was founded by the grant of Ministry of Science and Higher Education no. N N403 170637.

\section{Conflict of interest}

There is no conflict of interest.

\section{Author contributions}

Dr Kozak and Dr Dziewanowski were responsible for patient evaluation and data analysis, Dr Wajda, Dr Lapczuk and Dr Kurzawski were responsible for experiments, study design and manuscript preparation, Dr Lipski and Dr Drozdzik M were responsible for research design and manuscript revisions. 


\section{References}

Afonso M, de Oliveira Bello V, Shibli JA, Sposto MR (2003) Cyclosporine A-induced gingival overgrowth in renal transplant recipients. J Periodontol 74: 51-56.

Anderson TJ, Lapp CA, Billman MA, Schuster GS (1998) Effects of transforming growth factorbeta and platelet derived growth factor on human gingival fibroblasts grown in serum-containing and serum-free medium. J Clin Periodontol 25: 48-55.

Buduneli N, Kutukculer N, Aksa G, Atilla G (2001) Evaluation of transforming growth factor-beta1 level in crevicular fluid of cyclosporin A-treated patients. J Periodontol 72: 526-531.

Cotrim P, de Andrade CR, Martelli-Junior H, Graner E, Sauk JJ, Coletta RD (2002) Expression of matrix metalloproteinases in cyclosporine-related gingival fibroblasts is regulated by transforming growth factor (TGF)- $\beta 1$ autocrine stimulation. J Periodontol 73: 1313-1322.

Dreyfuss JL, Veiga SS, Coulson-Thomas VJ et al (2010) Differences in the expression of glycosaminoglycans in human fibroblasts derived from gingival overgrowths is related to TGFbeta up-regulation. Growth Factors 28: 24-33.

Edwards DR, Murphy G., Reynolds JJ et al (1987) Transforming growth factor beta modulates the expression of collagenase nad metalloproteinase inhibitor. EMBO J 6: 1899-1904.

Ellis JS, Morgan CI, Kirby JA, Taylor JJ, Thomason JM (2004) Plasma TGF- $\beta 1$ as a risk factor for gingival overgrowth. J Clin Periodontol 31: 863-868.

Grainger DJ, Mosedale DE, Metcalfe JC (2000) TGF- $\beta$ in blood: a complex problem. Cytokine Growth Factor Rev 11: 133-145.

Grigner DJ, Heathcote K, Chiano M et al (1999) Genetic control of the circulating concentration of transforming growth factor type $\beta 1$. Hum Mol Genet 8: 93-97.

Gurkan A, Afacan B, Emingil G, Toz H, Baskesen A, Atilla G (2008) Gingival crevicular fluid transforming growth factor- $\beta 1$ in cyclospotine and tacrolimus treated renal transplant patients without gingival overgrowth. Arch Oral Biol 53: 723-728.

James JA, Invin CR, Linden GJ (1998) Gingival fibroblast response to cyclosporine A and transforming factor beta 1. J Periodontal Res 33: 40-48.

Linden GJ, Haworth SE, Maxwell P et al (2001) The influence of transforming growth factor- $\beta 1$ gene polymorphisms on the severity of gingival overgrowth associated with concomitant use of cyclosporine A and a calsium channel blocker. J Periodontol 72: 808-814.

Margiotta V, Pizzo I, Pizzo G, Barbaro A (1996) Cyclosporine- and nifedipine-induced gingival overgrowth in renal transplant patients: correlations with periodontal and pharmacological parameters, and HLA-antigens. J Oral Pathol Med 25: 128-134.

McGaw WT, Porter H (1988) Cyclosporin-induced gingival overgrowth: an ultrastructural 
stereologic study. Oral Surg 65: 186-190.

Overall CM, Warana JL, Sodek J (1989) Independent regulation of collagenaze 72-kDa progelatinase and metalloproteinase inhibitor expression in human fibroblasts by transforming growth factor $\beta$. J Biol Chem 264: 1860-1869.

Pernu HE, Pernu HM, Huttunen KR, Nieminen PA, Knuuttila ML (1992) Gingival overgrowth among renal transplant recipients related to immunosuppressive medication and possible local background factors. J Periodontol 63: 548-553.

Pernu HE, Pernu LM, Huttunen KR, Nieminen PA, Knuuttila ML (2001) Gingival overgrowth among renal transplant recipients related to immunosuppressive medication and possible local background factors. J Periodontol 62: 548-553.

Pulleyn LJ, Newton R, Adcock IM, Barnes PJ (2001) TGFbetal allele association with asthma severity. Hum Genet 2001, 109: 623-629.

Radwan-Oczko M, Boratynska M, Zietek M, Dobosz T (2008) Transforming growth factor- $\beta 1$ gene expression and cyclosporine A-induced gingival overgrowth: a pilot study. J Clin Periodontol 35: 371-378.

Radwan-Oczko M, Boratynska M, Zietek M, Zoledziewska M, Jonkisz A (2006) The relationship of transforming growth factor- $\beta 1$ gene polymorphism, its plasma level, and gingival overgrowth in renal transplant recipients receiving different immunosuppressive regimens. $J$ Periodontol 77: 865-873.

Seymour RA, Thomason JM, Ellis JS (1996) The pathogenesis of drug-induced gingival overgrowth. J Clin Periodontol 23: 165-175.

Somacarrera ML, Hernandez G, Acero J, Moskow BS (1994) Factors relating to the incidence and severity of cyclosporine-induced gingival overgrowth in transplant patients. A longitudinal study. J Periodontal Res 65: 671-675.

Thomas DW, Baboolal K, Subtamanian N, Newcombe RG (2001) Cyclosporine A-induced gingival overgrowth is unrelated to allograft function in renal transplant recipients. J Clin Periodontol 28: 706-709.

Thomas DW, Newcombe RG, Osborne G (2000) Risk factors in the development of cyclosporineinduced gingival overgrowth. Transplantation 70: 552-556.

Thomasson JM, Ellis JS, Kelly PJ, Seymour RA (1997) Nifedipine pharmacological variables as risk factors for gingival overgrowth in organ-transplant patients. Clin Oral Invest 1: 35-39.

Wilson RF, Morel A, Smith D et al (1998) Contribution of individual drugs to gingival overgrowth in adult and juvenile renal transplant patients treated with multiple therapy. J Clin Periodontol 25: 457-464. 
Yoshida T, Nagata J, Yamane A (2005) Growth factors and proliferation of cultured rat gingival cells In response to cyclosporin A. J Periodontal Res 40: 11-19. 
Table 1 Patients' characteristics

\begin{tabular}{llll}
\hline Parameter & $\begin{array}{l}\text { Patients with gingival } \\
\text { overgrowth }(\mathrm{n}=84)\end{array}$ & $\begin{array}{l}\text { Patients without gingival } \\
\text { overgrowth }(\mathrm{n}=140)\end{array}$ & $\mathrm{p}$ \\
\hline Gender distribution $(\mathrm{F} / \mathrm{M})$ & $23 / 61$ & $49 / 91$ & 0.301 \\
Age (years)* & $42.2 \pm 13.1$ & $39.7 \pm 11.4$ & 0.233 \\
Place of residence: city/country & $44 / 40$ & $83 / 57$ & 0.332 \\
Smoking & 16 & 31 & 0.615 \\
Diabetes & 39 & 47 & 0.065 \\
Acute rejection & 3 & 20 & 0.011 \\
\hline All calculations performed by means of Fisher exact test, except *calculated by t-test &
\end{tabular}


Table 2 Characteristics of medication at monthly intervals after transplantation

\begin{tabular}{|c|c|c|c|c|c|c|}
\hline & 1 month & 2 months & 3 months & 4 months & 5 months & 6 months \\
\hline \multicolumn{7}{|c|}{ patients with gingival overgrowth $(n=84)$} \\
\hline $\begin{array}{l}\text { Cyclosporine } \\
\text { concentration } \\
(\mathrm{ng} / \mathrm{ml})\end{array}$ & $420.0 \pm 234.2$ & $380.1 \pm 206.7$ & $308.3 \pm 170.2$ & $306.3 \pm 198.2$ & $276.5 \pm 193.3$ & $280.8 \pm 179.4$ \\
\hline $\begin{array}{l}\text { Cyclosporine } \\
\text { dose }(\mathrm{mg} / \text { day })\end{array}$ & $\begin{array}{l}300.0 \pm 84.1 \\
(n=84)\end{array}$ & $\begin{array}{l}280.9 \pm 78.8 \\
(n=84)\end{array}$ & $\begin{array}{l}260.7 \pm 79.3 \\
(n=84)\end{array}$ & $\begin{array}{l}251.2 \pm 76.9 \\
(n=84)\end{array}$ & $\begin{array}{l}245.2 \pm 68.6 \\
(n=84)\end{array}$ & $\begin{array}{l}235.4 \pm 65.4 \\
(n=84)\end{array}$ \\
\hline $\begin{array}{l}\text { Diltiazem dose } \\
\text { (mg/day) }\end{array}$ & $\begin{array}{l}173.8 \pm 24.5 \\
(n=56)\end{array}$ & $\begin{array}{l}173.8 \pm 24.5 \\
(n=56)\end{array}$ & $\begin{array}{l}173.8 \pm 24.5 \\
(n=56)\end{array}$ & $\begin{array}{l}173.8 \pm 24.5 \\
(n=56)\end{array}$ & $\begin{array}{l}173.8 \pm 24.5 \\
(n=56)\end{array}$ & $\begin{array}{l}173.8 \pm 24.5 \\
(n=56)\end{array}$ \\
\hline $\begin{array}{l}\text { Verapamil dose } \\
\text { (mg/day) }\end{array}$ & $\begin{array}{l}174.5 \pm 72.2 \\
(n=28)\end{array}$ & $\begin{array}{l}174.5 \pm 72.2 \\
(n=28)\end{array}$ & $\begin{array}{l}174.5 \pm 72.2 \\
(n=28)\end{array}$ & $\begin{array}{l}174.5 \pm 72.2 \\
(n=28)\end{array}$ & $\begin{array}{l}174.5 \pm 72.2 \\
(n=28)\end{array}$ & $\begin{array}{l}174.5 \pm 72.2 \\
(n=28)\end{array}$ \\
\hline $\begin{array}{l}\text { Prednisone dose } \\
\text { (mg/day) }\end{array}$ & $\begin{array}{l}18.8 \pm 7.4 \\
(n=84)\end{array}$ & $\begin{array}{l}16.3 \pm 5.2 \\
(n=84)\end{array}$ & $\begin{array}{l}15.1 \pm 4.3 \\
(n=84)\end{array}$ & $\begin{array}{l}12.4 \pm 3.7 \\
(n=84)\end{array}$ & $\begin{array}{l}10.6 \pm 3.0 \\
(n=84)\end{array}$ & $\begin{array}{l}9.5 \pm 3.1 \\
(n=84)\end{array}$ \\
\hline \multicolumn{7}{|c|}{ patients without gingival overgrowth $(n=140)$} \\
\hline $\begin{array}{l}\text { Cyclosporine } \\
\text { concentration } \\
(\mathrm{ng} / \mathrm{ml})\end{array}$ & $413.2 \pm 258.1$ & $370.8 \pm 288.2$ & $326.8 \pm 263.5$ & $276.6 \pm 159.8$ & $296.9 \pm 195.6$ & $249.8 \pm 172.2$ \\
\hline $\begin{array}{l}\text { Cyclosporine } \\
\text { dose (mg/day) }\end{array}$ & $\begin{array}{l}282.4 \pm 99.1 \\
(n=140)\end{array}$ & $\begin{array}{l}274.4 \pm 88.2 \\
(n=140)\end{array}$ & $\begin{array}{c}256.5 \pm 85.4 \\
(n=140)\end{array}$ & $\begin{array}{l}254.9 \pm 83.6 \\
(n=140)\end{array}$ & $\begin{array}{l}246.2 \pm 77.2 \\
(n=140)\end{array}$ & $\begin{array}{l}238.4 \pm 73.0 \\
(n=140)\end{array}$ \\
\hline $\begin{array}{l}\text { Diltiazem dose } \\
\text { (mg/day) }\end{array}$ & $\begin{array}{l}172.2 \pm 30.4 \\
(n=104)\end{array}$ & $\begin{array}{l}172.2 \pm 30.4 \\
(n=104)\end{array}$ & $\begin{array}{l}172.2 \pm 30.4 \\
(n=104)\end{array}$ & $\begin{array}{l}172.2 \pm 30.4 \\
(n=104)\end{array}$ & $\begin{array}{l}172.2 \pm 30.4 \\
(n=104)\end{array}$ & $\begin{array}{l}172.2 \pm 30.4 \\
(n=104)\end{array}$ \\
\hline $\begin{array}{l}\text { Verapamil dose } \\
(\mathrm{mg} / \text { day })\end{array}$ & $\begin{array}{l}184.3 \pm 60.5 \\
(n=36)\end{array}$ & $\begin{array}{l}184.3 \pm 60.5 \\
(n=36)\end{array}$ & $\begin{array}{l}184.3 \pm 60.5 \\
(n=36)\end{array}$ & $\begin{array}{l}184.3 \pm 60.5 \\
(n=36)\end{array}$ & $\begin{array}{l}184.3 \pm 60.5 \\
(n=36)\end{array}$ & $\begin{array}{l}184.3 \pm 60.5 \\
(n=36)\end{array}$ \\
\hline $\begin{array}{l}\text { Prednisone dose } \\
(\mathrm{mg} / \text { day })\end{array}$ & $\begin{array}{l}17.9 \pm 4.5 \\
(n=140)\end{array}$ & $\begin{array}{l}15.2 \pm 3.0 \\
(n=140)\end{array}$ & $\begin{array}{l}13.4 \pm 3.4 \\
(n=140)\end{array}$ & $\begin{array}{l}12.1 \pm 2.5 \\
(n=140)\end{array}$ & $\begin{array}{l}11.9 \pm 2.6 \\
(n=140)\end{array}$ & $\begin{array}{l}11.9 \pm 2.6 \\
(n=140)\end{array}$ \\
\hline
\end{tabular}


Table 3 Distribution of tgfb1 alleles and genotypes among kidney transplant patients with and without gingival overgrowth

\begin{tabular}{|c|c|c|c|c|c|c|}
\hline & \multicolumn{2}{|c|}{$\begin{array}{l}\text { Gingival Overgrowth } \\
\qquad(n=84)\end{array}$} & \multicolumn{2}{|c|}{$\begin{array}{l}\text { Healthy gingiva } \\
\quad(n=140)\end{array}$} & \multirow[t]{2}{*}{$p$ value } & \multirow[t]{2}{*}{ OR $(95 \% C I)$} \\
\hline & $n$ & $(\%)$ & $n$ & (\%) & & \\
\hline \multicolumn{7}{|l|}{ Genotype $-800 \mathrm{G}>\mathrm{A}$} \\
\hline GG & 78 & $(92.9)$ & 120 & $(85.7)$ & - & - \\
\hline GA & 6 & (7.1) & 19 & (13.6) & 0.188 & $0.48(0.18-1.27)$ \\
\hline AA & 0 & $(0.0)$ & 1 & $(0.7)$ & 1.000 & - \\
\hline minor allele carriers $(\mathrm{GA}+\mathrm{AA})$ & 6 & $(7.1)$ & 20 & $(14.3)$ & 0.132 & $0.46(0.17-1.20)$ \\
\hline minor allele frequency & 6 & $(3.6)$ & 21 & (7.5) & 0.103 & \\
\hline \multicolumn{7}{|l|}{ Genotype $-509 \mathrm{C}>\mathrm{T}$} \\
\hline $\mathrm{CC}$ & 43 & $(51.2)$ & 61 & $(43.6)$ & - & - \\
\hline $\mathrm{CT}$ & 32 & $(38.1)$ & 63 & $(45.0)$ & 0.306 & $0.72(0.40-1.28)$ \\
\hline TT & 9 & $(10.7)$ & 16 & $(11.4)$ & 0.657 & $0.80(0.32-1.97)$ \\
\hline minor allele carriers $(\mathrm{CT}+\mathrm{TT})$ & 41 & $(48.8)$ & 79 & $(56.4)$ & 0.272 & $0.74(0.43-1.27)$ \\
\hline minor allele frequency & 50 & $(29.8)$ & 95 & $(33.9)$ & 0.404 & \\
\hline
\end{tabular}

Genotype $+869 \mathrm{~T}>\mathrm{C}$

$\begin{array}{ccccccc}\text { TT } & 34 & (40.5) & 50 & (35.7) & - & - \\ \text { TC } & 38 & (45.2) & 65 & (46.4) & 0.652 & 0.86(0.47-1.55) \\ \text { CC } & 12 & (14.3) & 25 & (17.9) & 0.424 & 0.71(0.31-1.55) \\ \text { minor allele carriers (TC+CC) } & 50 & (59.5) & 90 & (64.3) & 0.480 & 0.82(0.47-1.42) \\ \text { minor allele frequency } & 62 & (36.9) & 115 & (41.1) & 0.404 & \end{array}$

Genotype $+915 \mathrm{G}>\mathrm{C}$

$\begin{array}{ccrcrcc}\text { GG } & 72 & (85.7) & 120 & (85.7) & - & - \\ \text { GC } & 12 & (14.3) & 20 & (14.3) & 1.000 & 1.00(0.46-2.16) \\ \text { CC } & 0 & (0.0) & 0 & (0.0) & 1.000 & - \\ \text { minor allele carriers (GC+CC) } & 12 & (14.3) & 20 & (14.3) & 1.000 & 1.00(0.46-2.16) \\ \text { minor allele frequency } & 12 & (7.1) & 20 & (7.1) & 1.000 & \end{array}$

All calculations performed by means of Fisher exact test, using homozygotes for a major (more frequent) allele or major allele frequency as reference. 
Table 4 Frequency of $T G F B 1$ haplotypes among kidney transplant patients with and without gingival overgrowth.

\begin{tabular}{lccccc}
\hline & $\begin{array}{c}\text { Gingival Overgrowth } \\
(2 n=168)\end{array}$ & \multicolumn{2}{c}{ Healthy gingiva } & (2n=280) \\
& $n$ & $(\%)$ & $n$ & $(\%)$ & \\
\hline G_C_T_G & 100 & $(59.5)$ & 144 & $(51.4)$ & $* 0.116$ \\
G_T_C_G & 50 & $(33.9)$ & 95 & $(29.8)$ & 0.236 \\
G_C_C_C & 12 & $(7.2)$ & 20 & $(7.1)$ & 0.848 \\
A_C_T_G & 6 & $(7.5)$ & 21 & $(3.6)$ & 0.063
\end{tabular}

All calculations performed by means of Fisher exact test, using frequency of major haplotype as reference, except* - in relation to the sum of other haplotypes.

EH program (Jurg Ott, Rockefeller University, New York) was used to estimate haplotype frequencies based on results of typing for following SNPs: $-800 \mathrm{G}>\mathrm{A},-509 \mathrm{~T}>\mathrm{C},+869 \mathrm{~T}>\mathrm{C}$, $+915 \mathrm{G}>\mathrm{C}$. Among 16 potentially possible haplotypes derived from 4 SNPs, only four were observed in the studied sample of kidney transplant patients, with respective frequencies: G_C_T_G (0.545), G_T_C_G (0.324), G_C_C_C (0.071), and A_C_T_G (0.060). 


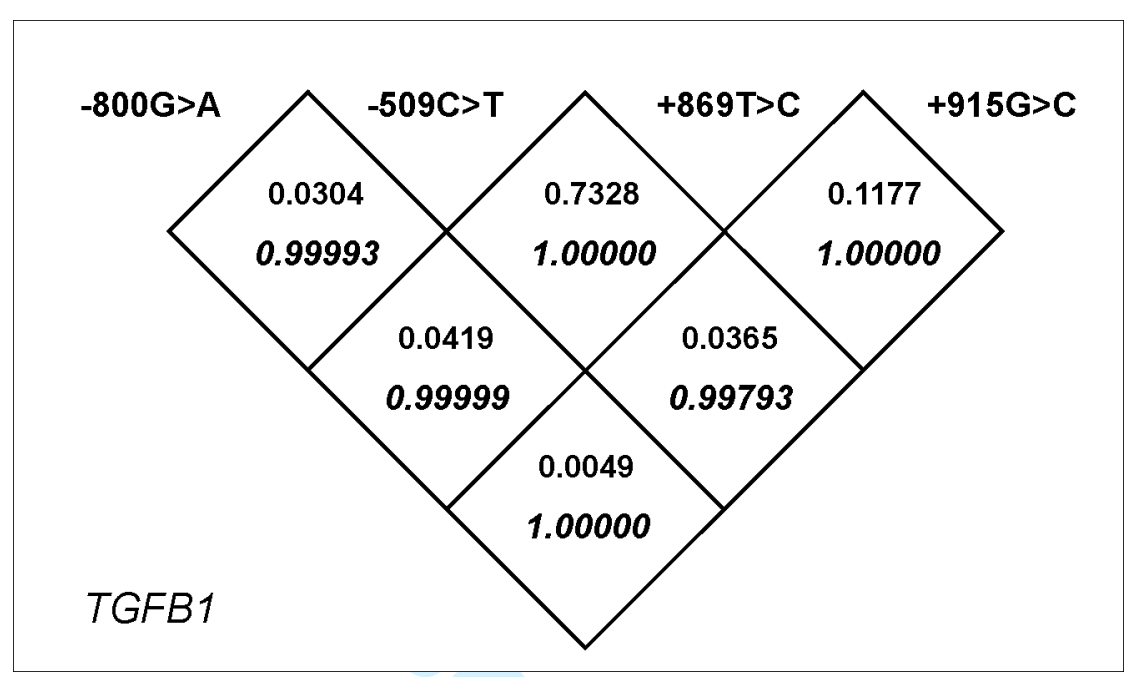

Figure 1. Pairwise LD between the studied TGFB1 SNPs, estimated on base of analysis of all study subjects $(n=224)$. Numbers represent $r^{2}$ (square correlation coefficient), and $D^{\prime}$ values (italics). 